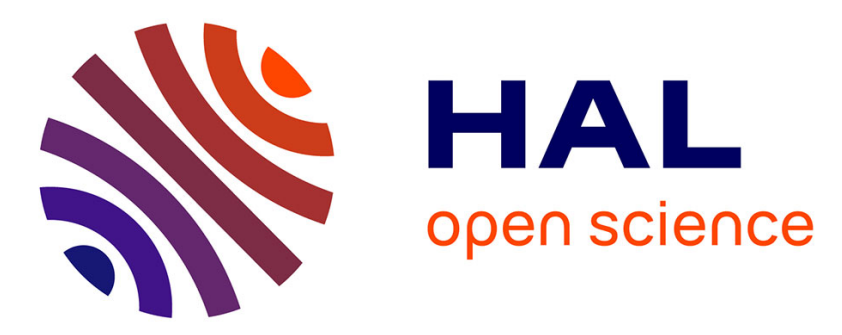

\title{
Results of the First Trial Assessing Adjuvant Tyrosine Kinase Inhibitors in Renal Cell Carcinoma Do Not reASSURE
}

\author{
Idir Ouzaid, Karim Bensalah
}

\section{- To cite this version:}

Idir Ouzaid, Karim Bensalah. Results of the First Trial Assessing Adjuvant Tyrosine Kinase Inhibitors in Renal Cell Carcinoma Do Not reASSURE. European Urology, 2015, 68 (3), pp.542-543. 10.1016/j.eururo.2015.04.042 . hal-01260239

HAL Id: hal-01260239

https://hal-univ-rennes1.archives-ouvertes.fr/hal-01260239

Submitted on 4 Feb 2016

HAL is a multi-disciplinary open access archive for the deposit and dissemination of scientific research documents, whether they are published or not. The documents may come from teaching and research institutions in France or abroad, or from public or private research centers.
L'archive ouverte pluridisciplinaire HAL, est destinée au dépôt et à la diffusion de documents scientifiques de niveau recherche, publiés ou non, émanant des établissements d'enseignement et de recherche français ou étrangers, des laboratoires publics ou privés. 
Results of the First Trial Assessing Adjuvant Tyrosine Kinase Inhibitors in Renal Cell Carcinoma Do Not reASSURE

Idir Ouzaid $^{\mathrm{a}}$, Karim Bensalah ${ }^{\mathrm{b}}$

${ }^{a}$ : Department of Urology, Bichat-Claude Bernard Hospital and Paris Diderot University, Paris, France

${ }^{\mathrm{b}}$ : Department of Urology, CHU Rennes and University of Rennes, Rennes, France

Corresponding author : idir.ouzaid@free.fr 


\section{Results of the First Trial Assessing Adjuvant Tyrosine Kinase Inhibitors in Renal Cell Carcinoma Do Not reASSURE}

The ASSURE trial (NCT00326898) was designed to evaluate the ability, in the adjuvant setting, of two oral antiangiogenic agents to prevent disease recurrence in patients with highrisk localized renal cell carcinoma (RCC) [1].

The trial randomly assigned 1943 patients with completely resected RCC to 1-yr treatment with sorafenib (400 mg twice daily, $n=649$ ), sunitinib (50 mg/day for 4 wk of every $6 \mathrm{wk}, n$ $=647)$, or a placebo $(n=647)$. The primary endpoint was disease-free survival (DFS). The study was designed to detect a $25 \%$ reduction in the hazard ratio (HR), corresponding to an improvement of $1.9 \mathrm{yr}$ in median DFS.

An interim analysis using $62 \%$ of the anticipated data showed that 5-yr DFS rates varied slightly from $52.8 \%$ to $55.8 \%$ across the three arms, yielding HRs of 0.98 for sorafenib and 1.01 for sunitinib compared to placebo. Similarly, the 5-yr overall survival ranged from $76.9 \%$ to $80.7 \%$, yielding HRs of 0.93 for sorafenib and 1.10 for sunitinib compared to placebo. The investigators also performed an analysis for a clear-cell RCC subgroup (80\% of the patients in each arm) and found HR values of approximately 1 in each group. Therefore, the Data and Safety Monitoring Board recommended that the trial be terminated with immediate release of the results. The study findings suggest that neither sorafenib nor sunitinib offers benefits greater than those of placebo. For this reason, patients with locally advanced RCC should not receive adjuvant treatment with either sorafenib or sunitinib. A negative trial always raises concerns regarding contamination, power, or design biases. First, patient dropout because of poor tolerance is a very important flaw in every adjuvant trial. Thus, the expected improvements were shifted slightly to $4.9 \mathrm{yr}$ for placebo and $6.5 \mathrm{yr}$ for treatment. In fact, $70 \%$ and $63 \%$ of patients experienced grade 3 or higher adverse events with sorafenib and sunitinib, respectively (vs $24 \%$ in the placebo arm). However, this protocol amendment did not underpower the trial because accrual was higher than expected (from 444 to 641 patients per arm) and the proportion of high-risk patients according to the University of California-Los Angeles integrated staging system [2] shifted from 30\% to 50\%, allowing a consistent $25 \%$ difference in the PFS. In addition, toxicity was well tolerated for dose reduction followed by dose escalation. As a result, patients could receive a median of eight and nine cycles in the tyrosine kinase inhibitor (TKI) and placebo arms, respectively. To evaluate the extent of the impact of dose reduction on outcomes, subgroup analyses for patients who could tolerate a full TKI dose are ongoing.

Second, the 1-yr duration for adjuvant treatment might be questioned and could be considered insufficient. Upcoming Sorce (placebo vs sorafenib 1 or 3 yr, NCT00492258) and Atlas (placebo versus axitinib for at least $1 \mathrm{yr}$ and up to $3 \mathrm{yr}$, NCT01599754) trials will probably address this issue.

Finally, all patients in adjuvant trials are selected using risk stratification tools based on TNM staging, pathology, and performance status. More elaborate tools involving genomic sequencing and molecular biology of the tumors and the host are currently lacking. Analysis of tissue and blood samples collected from all trials might provide us with an insight into how biology could help to improve patient selection for adjuvant therapy because of poor "biological" prognosis.

In conclusion, while awaiting the results of ongoing adjuvant trials, we should keep in mind that use of TKIs to prevent suspected recurrence of micrometastases in high-risk RCC patients may be a dead end, as has been demonstrated for colon $[3,4]$ and breast cancers [5]. We should consider investigation of immunologic therapies, such as PD1 and PDL1 antagonists, for this setting. 
Conflicts of interest: The authors have nothing to disclose.

\section{References}

1. Haas NB, Magnolia J, Uzzo RG. Initial results from ASSURE (E2805): adjuvant sorafenib or sunitinib for unfavorable renal carcinoma, an ECOG-ACRIN-led, NCTN phase III trial. J Clin Oncol 2015;33(Suppl 7):403.

2. Zisman A, Pantuck AJ, Dorey F, et al. Improved prognostication of renal cell carcinoma using an integrated staging system. J Clin Oncol 2001;19:1649-57.

3. Allegra CJ, Yothers G, O;Connell MJ, et al. Bevacizumab in stage II-III colon cancer: 5-year update of the National Surgical Adjuvant Breast and Bowel Project C-08 trial. J Clin Oncol 2013;31:359-64.

4. de Gramont A, Van Cutsem E, Schmoll HJ, et al. Bevacizumab plus oxaliplatin-based chemotherapy as adjuvant treatment for colon cancer (AVANT): a phase 3 randomised controlled trial. Lancet Oncol 2012;13:1225-33.

5. Cameron D, Brown J, Dent R, et al. Adjuvant bevacizumab-containing therapy in triplenegative breast cancer (BEATRICE): primary results of a randomised, phase 3 trial. Lancet Oncol 2013;14:933-42.

Idir Ouzaid $^{\mathrm{a}, *}$, Karim Bensalah ${ }^{\mathrm{b}}$

a Department of Urology, Bichat Claude Bernard Hospital and Paris Diderot University, Paris, France

${ }^{\mathrm{b}}$ Department of Urology, CHU Rennes and University of Rennes, Rennes, France

* Corresponding author. Department of Urology, Bichat-Claude Bernard Hospital, 46 rue Henri Huchard, 75018 Paris, France. Tel. +33 140258935. E-mail address: idir.ouzaid@free.fr (I. Ouzaid). 